\title{
Sartrean Freedom and Responsibility in Rousseau's Emile
}

\author{
Beljun P. Enaya ${ }^{1}$ and Al Franjon Villaroya ${ }^{2}$ \\ 1,2Visayas State University, Baybay City, Leyte, Philippines
}

\section{Article history:}

Submitted: 14 February 2021

Revised: 16 March 2021

Accepted: 25 March 2021

\section{Keywords:}

Jean-Paul Sartre

Freedom

Responsibility

Jean-Jacques Rousseau,

Philosophy of education
ABSTRACT. This paper discusses Jean-Paul Sartre's existentialist interpretation of Jean-Jacques Rousseau's philosophy of education, or Emile. It aims to show the Sartrean concept of freedom and responsibility in understanding education, as shown in Emile and his tutor's narrative. It utilizes Sartre's significant works, such as Being and Nothingness, and Existentialism is a Humanism, in explicating the Sartrean concept in Rousseau's book, Emile. Existentialist hermeneutics helps the paper to re-interpret the text of Emile. It argues that Rousseau's philosophy of education, as demonstrated by Emile and his tutor, implicitly manifests absolute freedom and responsibility in the learning process. Thus, this paper provides a Sartrean existentialist perspective of understanding Rousseau's Emile.

\subsection{Introduction}

White (2001) has pointed out that the concept of freedom has been a significant "ingredient" since ancient times. The philosophical reflection on freedom becomes more emphasized through the existentialist movement in the $19^{\text {th }}$ century in the philosophy of Soren Kierkegaard and Friedrich Nietzsche; and, in the 20 $0^{\text {th }}$ century, the movement becomes clearer in Sartre's self-proclaimed existentialism (White, 2001; Sartre, 2007). The existentialist theme still echoes in various struggles of the people. In the victory of freedom over tyrannical oppression, people always call out the freedom to defend themselves. Today, individuals strive to live freely. Once this freedom is transgressed, conflicts explode, and people fight again, not just because they want to be free but also because they want to persuade others that their concept of freedom is the real one. The conflict only implies that one cannot escape from being free, like how Sartre (2007) popularly says that "man is condemned to be free," and from that, responsibility comes. When this concept of freedom is put into the philosophy of education, it would seem less achievable because most formal educational systems and educators impose their self-centered motives on the learning process. Recently, academic freedom has been raised when the Department of National Defense has unilaterally revoked the 1989 accord with the University of the Philippines. The Commission on Higher Education's call for defining academic freedom is pathetic for educators (Yap, Subingsubing, \& Valenzuela, 2021). That issue only implies that up to now, freedom in education is still a work-in-progress. Furthermore, today's colleges and universities are very concerned with producing graduates to achieve specific qualifications required of them: neglecting the student's fundamental being. In that sense, there are issues on the learner's centeredness in how it is actualized in the educational system. Consequently, these issues would force us to question the quality of education for the learner's well-being.

Jean-Jacques Rousseau has already introduced to the world the naturalistic way of educating a learner. His contention is that a person must leave the society that corrupts the nature of man to learn naturally. The method is so radical that it leads the person to his state of being good. However, the question lies on the "how," which pushes Rousseau to write a book, Emile, that narrates a learner's story and demonstrates the learning process. His Emile is the most relevant work on education after Plato's Republic (Wokler, 2001). It becomes influential, or predecessor, in modern education (Oelkers, 2002). Simone de Beauvoir, a feminist existentialist and partner of Jean-Paul Sartre, admires Emile and is influenced by it (Scholz, 2010); but that cannot be deduced that Sartre is a fan of Emile also. Although Darnell (1992) has argued that Sartre has a "huge debt" to Rousseau in various aspects and Brosman (1985) has explained the parallelism between Rousseau and Sartre, both of them have not bothered much to consider the connection between Emile and Sartre's existentialist education. Nonetheless, even if Sartre is not famous in terms of education (and in this case, Emile), Sartrean freedom and responsibility is useful in teaching the students to avoid being passive and uncritical towards the learning process (Detmer, 2005; White, 2001). 
With the sudden shift to a "new normal" way of education due to the COVID-19 pandemic, it is necessary to consider the idea of freedom and responsibility in the context of education. While modern existentialism, such as Sartre, finds meaning during the post-war era (Kearney, 2003), it is also equally important to reflect on existential questions in today's crisis. Are the students and teachers free today? Thousands of articles on the pandemic come out from different platforms. However, the need to go back to nature and distance oneself from society is a primary strategy in Emile to combat the corrupt society (Rousseau, 1979). Hence, with the profound and radical concept of freedom and responsibility of Sartre, Rousseau's learning process shall ultimately reach its goal while reconciling the limiting condition these days. In that sense, this paper does not seek to follow how Kraus (1980) argues the compatibility of Sartre's concept with the Summerhill Environment; but, instead, it offers another way of understanding Emile, and thus agrees with the suggestion from the study of Petcu (2012) to contribute in a growing need for research on the implications of Sartre's concept.

Moreover, the rise of academic capitalism in the $21^{\text {st }}$ century, which is the maximization of scientific research to earn profits, creates more obstacles in a true learning environment (Jessop, 2018). With the current crisis, this phenomenon pushes us more to rethink the essence of education but in an existential manner that leads to a meaningful education. It is not to say that the practice of freedom must be forced in classroom activities because it is a paradox to force someone to be free (Vandenberg, 1967). However, existentialist education counters the exploitation of the person and contributes to the realization of self (Koirala, 2011). While Landau (2012), along with other critics, claims that Sartre's absolute freedom is conflicting with empirical reality. White (2001), Dinitto (1980), Overholt (1969), and Armitage (1990) believe that Sartrean education and its implication support the possibility of interpreting and contextualizing Sartrean freedom and responsibility in a concrete learning environment. Thus, with the lack of literature on Emile's existential meaning, this paper aims to uncover and focus on the Sartrean freedom and responsibility shown in Emile and attempts to provide a new existentialist interpretation.

Finally, it would also appear that a Sartrean concept cannot be contextualized or applied in a person's situation, e.g., Emile, who believes in a given nature. This study attempts to clarify the possibility of having a given purpose or nature while exercising absolute freedom, knowing that the Sartrean concept is best contextualized in the atheistic approach or non-given nature or purpose of man. Also, nowadays, there are conflicting issues on how freedom is exercised in the learning process. Some students are trapped in the mentality that they attend classes due to society's demands to comply with academic qualifications. Hence, the researcher hopes that this study will help the students to understand better the aim of education while they hold onto the foundation of freedom. It sees to it that the students will see themselves as persons responsible for their own lives as they learn themselves from any endeavor. Lastly, this paper serves as a tool to motivate educators to exercise absolute freedom for the sake of effective education without destroying the student's conscious choice and develop their strategies to improve education. In this manner, the educators will realize that there is no contradiction in having absolute freedom in the field of education. Therefore, this paper emphasizes the importance of molding the student to become a good, absolutely free, and responsible person.

\subsection{Framework of the Study}

Jean-Paul Sartre is the first philosopher to adopt the term "existentialism" to his own philosophy. However, the existentialist view has been demonstrated by or clearly started with Soren Kierkegaard. The existentialist thought is often viewed differently by various thinkers and writers. English (1966), for instance, says that there are significantly distinctive perspectives on existentialism that one has to look into the meaning of existentialism and that which is referred to as "a philosophical school, a literary movement, or an attitude towards life, which is expressed now in one way, now in another." English continues to say that in the study of existentialism, one will cite Karl Jaspers, Gabriel Marcel, and Martin Heidegger often for contemporary existentialists, Albert Camus for expressing lots of existentialist ideas in his writings, Soren Kierkegaard in the 19th century, and Jean Paul Sartre in 20th century. Existentialism appears to be difficult to trace its beginning because even St. Augustine of Hippo and Blaise Pascal have been claimed as existentialists as the likes of Friedrich Nietzsche and Feodor Dostoevsky. However, most often, Kierkegaard usually claims the title of the "father of existentialism" and Jean Paul Sartre as the one who provisionally defines existentialism. 
This study is solely anchored on Jean-Paul Sartre's existentialism. Sartre's major work in 1943, Being and Nothingness, discusses thoroughly his philosophy of freedom. The concept of freedom and responsibility is succinctly explained and defended when Sartre wrote Existentialism is a Humanism in 1946 , from which he also definitely claimed to be an existentialist. This label is not admitted by those who are named existentialists like Heidegger.

For Sartre (2007), existentialism refers to man as nothing but is capable of making of himself. It points out the precedence of existence in relation to the essence. This means that man exists first, and nothing exists prior to what he becomes and that becoming is the result of the spontaneous choosing by the will. In this case, existentialism's initiative is making a man take full responsibility for his existence.

In Being and Nothingness, Sartre (1992) explains intensively the phenomenology of being. The idea of existence comes, at least, with two types of beings: being-for-itself and being-in-itself. On the one hand, being-for-itself is a conscious being. Its consciousness is not pure consciousness, but it is always conscious of an object. It is normally applied to a human being. On the other hand, being-in-itself is to get the attention of the "absolute unity that things have with themselves (1992)." It is without consciousness and causally determined, and without freedom. As a being conscious of itself, being-for-itself's object is the being-in-itself. The being-for-itself names the human condition of nothingness or nihilation, and that human condition is that humans are no-thing, which also means no particular thing; and nothingness is the foundation of man to make himself and to will for action (Jugo, 2012; Wall, 2005).

Sartre believes that man is absolutely free, i.e., man is freedom, and this freedom comes with the concept of responsibility that is at the same time attached to man's consciousness (Dilman, 2013; Coppleston, 2003; Schick \& Vaughn, 2006). For Sartre, there are no a-prior values of man, but man creates values from which he is responsible for his chosen action (d'Anjou, 2007). Whether the person chooses or does not choose, he is actually free. Even if he does not choose, he is still responsible for his action regardless of whether it is by force or voluntariness. Responsibility is, therefore, "the consciousness (of) being the incontestable author of an event or of an object" (Sartre, 1992, p.707).

Founded on Sartrean existentialism, this paper interprets Jean-Jacques Rousseau's philosophy of education. In Emile, or On Education, Rousseau (1979) believes that education comes from nature. If plants grow by cultivation, men are shaped by education. There is a great emphasis on nature as the fundamental ingredient in the educational process. This nature is that which exists prior to the corruption of man in society. However, the seemingly conflicting concepts of human nature between Rousseau and Sartre are not necessarily contradictory. The essential grounds of the two do not affect much in the study; instead, they create a possibility of convergence from which a certain goal or direction emerges.

In Starting with Rousseau, Delaney (2009) has pointed out that the concept of education is not without a direction. In Emile, the concern is how to raise a child from birth to adult. The goal is to show how to be a well-educated man, or in other words, a good man. This good man is a welldeveloped natural man. Consequently, along with becoming a natural man, education aims to attain a noble society free from corruption. Moreover, the goal of Emile is properly understood in the moral sense of education. Emile does not primarily subscribe to a certain profession to attain in the learning process. "Emile" is not to be educated to gain any academic degrees or awards of recognition by an institution. He is not going to choose a career such as a doctor, engineer, or teacher. However, he is to look into his natural capabilities to discover things by himself while preserving the nature of man in him. Consequently, he becomes ready to enter into society. Thus, the educational program is to imitate man's nature. In effect, it must eliminate the conflict between man's nature (its goodness) and social pressure (what the society describes him to be).

Therefore, in this paper, Sartrean existentialism sets the paradigm in understanding the philosophy of education as lived by Emile in the conception of Rousseau. It consequently excavates the Sartrean freedom and responsibility in education.

\subsection{Methods}

This paper explores Rousseau's (1979) philosophy of education through his book Emile or On Education translated in English by Allan Bloom. Sartre's (1992) existentialist lens through the English version of his works on Being and Nothingness and Existentialism is a Humanism facilitate in looking 
into the Sartrean elements of Rousseau's Emile. Other works of Rousseau are not utilized here to focus solely on Emile.

This paper employs existentialist hermeneutics to extract meanings from the text of Emile using the Sartrean lens. Existentialist hermeneutics is a combination of an existentialist framework and hermeneutic method. It is an approach that interprets the text beyond the existing meanings. Rudolf Bultmann and Paul Tillich have used existentialist hermeneutics to understand the scripture. In their approach, the understanding of the bible becomes more significant and acceptable to the modern man (Arnett, 1966). Just as Dinkler (1952) and Arnett (1963) believe that Bultmann's existentialist interpretation is necessary to understand myths anthropologically or existentially, the existentialist interpretation of this paper is also necessary since Emile is not a definite manual but a conceptual set up for education. As much as it respects the author's contextual meaning (Emile), it allows the researcher to provide existential interpretation through a certain perspective (in this case, a Sartrean lens). Thus, Emile is interpreted from the perspective of Sartrean existentialism.

\subsection{Results and Discussion}

Jean-Jacques Rousseau believes that human nature is fundamentally good and human beings are free. However, the natural goodness of man is corrupted once he entered society. Allan Bloom explains that Emile is written to defend man against the bourgeois, who identifies his good apart from the common good (Rousseau, 1979). For this reason, Emile posits a return of man to his natural goodness. Finally, Emile is a conceptual setup based on the existing facts, not rather an actual manual instruction for education.

The first part of the results and discussion section explains the general ideas of Sartre in Emile's context; the next part proceeds to the presentation and discussion of the Sartrean elements in Emile. Furthermore, there is no problem in using the Sartrean concept in Emile since the object of our conscious self is the learner, Emile. Freedom and responsibility belong to man and certainly belong to Emile as a learner in Rousseau's educational philosophy. White (2001) has expressed the possibility of using Sartrean ideas in education. Besides, there is no doubt that we also include the tutor's role in our analysis as he projects the critical concepts of Rousseau's educational ideas and has an essential role in Emile's life. This approach is what Sartre desired: to contextualize his concepts (Pitt, 2015). Thus, to look at Emile's freedom and responsibility from Rousseau's perspective is to depart from this study.

\section{The Basic Sartrean Concepts in Emile}

\section{Being-in-itself and Being-for-itself in Emile}

Being-in-itself is that which is without consciousness and a fixed or permanent reality. Simultaneously, being-for-itself is a conscious being, a being that is not yet (Sartre, 1992). For instance, a stone, a past life, or a mere situation is being-in-itself, while a human person or any conscious of itself creature is a being-for-itself. In Emile, the tutor and Emile himself are under the category of being-for-itself. As we limit it to two identifications, these two people are conscious beings and conscious of the being-in-itself as far as the story in Emile is concerned. Their objects of consciousness are, at least, Emile and the tutor themselves, the nature, and the things they contracted. The last two mentioned (nature and things) and society, taken as a fixed concept, are considered the being-in-itself. Let us simply distinguish them that way for the sake of preliminary analysis.

The being of Emile is a being-for-itself. Emile as a natural man, is for himself. Rousseau believes that: "Natural man is entirely for himself. He is numerical unity, the absolute whole which is relative only to itself or its kind (Rousseau, 1979, p. 39)." The tutor entirely respects this reality of the beingfor-itself of the learner as shown in the learning process throughout the development: from childhood to young adulthood. It is shown by the fact that the tutor does not restrict or control the learner, and the tutor lets the learner do things by and for himself. In the passage, the tutor must respect the freedom of Emile in the process: "Command him nothing, whatever in the world it might be, absolutely nothing. Do not even allow him to imagine that you might pretend to have any authority over him (Rousseau, 1979, p. 91)." With a non-authoritarian presence, Emile creates more meaning for himself. 
Being a man entails being free. Otherwise, he becomes being-in-itself, such as sedentary, completely unconscious, and not free.

\begin{abstract}
In continuing to act the same way as a man, he only adds the empire of habit to freedom's sweetness. The active life, work with his hands, exercise, and movement have become so necessary that he could not give them up without suffering. To reduce him all of a sudden to a soft and sedentary life would be to imprison him, to enchain him, to keep him in a violent and constrained state (Rousseau, 1979, p. 432).
\end{abstract}

\title{
Education as Negation
}

From the start, Rousseau assumes that Emile cannot be educated by society, which is corrupt in itself and the source of future corruption if not resolved. Education does only come into Emile's world by the being-for-itself. It is the continuous reflection of the fullness of nature from which Emile's consciousness exists as such. Therefore, through a Sartrean analysis, Emile is by which consciousness exists. It essentially nihilates and gives rise to something other than what it is, just like Emile being able to pass his episodic learning stage.

Negative education is a human effort. There is no education when Emile does nothing to learn. Emile has to do things in order to learn. The constant contact with nature, or things, or men shows negation with other beings to make something new apart from what is already given.

\section{Freedom and Responsibility}

Speaking of freedom and responsibility is talking about its absoluteness in any given situation. Note that Sartrean freedom refers to the very being of the human being or the "being-for-itself". In contrast, responsibility refers to "the consciousness (of) being the incontestable author of an event or of an object (Sartre, 1992, p. 707)." The facticity provided in this study is Emile or philosophy of education, Emile himself and the tutor. Thus, the question lies in the absolute freedom and responsibility of education and its people.

In Emile, Rousseau (1979) believes that freedom is the foundation of all essences. This fundamental concept already implies that freedom enters into the gap between existence and the nature of man. Of course, we should not forget that Rousseau believes that the Author of everything provides man's nature as good, while Sartre retains his position of man's non-given nature. However, it is previously mentioned, and it is good to remind ourselves, that Sartre (1992), in his essay on existentialism, believes that it does not matter if the Author of everything exists or not but the most important thing that we can grasp is that existence precedes essence, which means that the first truth is the existence of an individual and the meaning of self is found later or determined by oneself. With that, the problem of finding the essence of man is the aim of Emile.

The key to Emile's absolute freedom and responsibility is how Emile undergoes education and how he responds to the facticity confronted to him in each stage of his life. The negation as provided or as a result in education brings about something new to the learner's being. Thus, Rousseau says, "Everything we do not have at our birth and which we need when we are grown is given us by education (Rousseau, 1979, 38)." Let us discuss this element further in the next section to investigate Emile's freedom and responsibility.

\section{Goodness as the Project of Freedom}

The goal of Emile is to reach the natural man or the goodness of man. This goal is also the goal of freedom, the goal of the being-for-itself. How does one conclude that freedom is for goodness? Rousseau believes that the human being's goodness is identical to his natural freedom. It is evident that throughout Emile, the process of education is freedom in itself, and its end is freedom. "Emile is to have perfect freedom - what Rousseau called natural freedom (Nash et al., 1965, p. 235)." Even Rousseau himself clearly says that the first of all good is not authority or power but freedom. Thus, freedom is the greatest good (Delaney, 2009; Rousseau, 1979). 


\title{
Emile as a Learner: Absolutely Free and Responsible
}

The persisting, or the controversial issue at hand, is the reality of Emile's absolute freedom and responsibility in the mind of Rousseau as manifested in his philosophy of education. At this moment, let us particularly look into the life of Emile.

\section{Emile and the Act of Learning}

Delaney (2009) explains that Emile's stages of the learning process do not define what he is, but he is what he is not. Emile's first three stages show an evident struggle of negating himself from the given existence and environment. He has little limbs, delicate parts of the body, but he stretches them out little by little, leaves one episode of growth, and proceeds to the other. The learning process respects the freedom of Emile. It preserves the absoluteness of freedom and therefore trains Emile to be responsible for his freedom. The negative education employed in Emile manifests recognition of the freedom and responsibility of Emile. The method of discovering certain values by Emile himself is a freedom in itself that teaches him to be "answerable" by his own discovery. Let us take, for instance, the time which Emile learns about justice and property:

\begin{abstract}
The tutor and Emile come upon a plot of land, and the tutor explains that Emile can have this land and cultivate it. The tutor even volunteers to help Emile be his 'under-gardener'. Together, they plant beans, water them, and care for them every day. Through joining his labour to the land, Emile comes to understand the notion of property. He feels a connection and even a right to his little garden. However, one day, when Emile and the tutor come to the garden, they find all the beans have been dug up. At first, Emile is outraged that someone destroyed his property, the fruits of his labour. He and the tutor come to find out it was the gardener, Robert, who dug up the beans. But when Emile confronts Robert, he finds that the gardener had, long before Emile planted his beans, planted melons in the same plot of land. So ironically, it is Emile who must apologize for destroying Robert's property and make things right; he now has a primitive sense of justice (Delaney, 2009, p. 75-76).
\end{abstract}

The circumstance above only depicts a learning process that allows freedom to prosper and becomes more evident in the real situation. The responsibility is absolute as well when Emile recognizes and accepts his own doing. The fruit of acceptance, which is in good faith, is the discovery of values. Emile is absolutely free and responsible; in freedom, he is the cause of his own doing. Thus, he is responsible for his own action.

\footnotetext{
... his freedom is only a similar power or one derived from the former. One chooses the good as he has judged the true; if he judges wrong, he chooses badly. What, then, is the cause that determines his will? It is his judgment. And what is the cause which determines his judgment? It is his intelligent faculty, it is his power of judging: the determining cause is in himself (Rousseau, 1979, p. 280).
}

Another thing to note is that the learning process does not subscribe to habit, but it cultivates no-habit. This no-habit only entails that Emile is a learner who is not fixed, not being-in-itself, in his learning. His learning process is on-going; it does not stop from one or two stages nor accepts beingin-itself without nihilating it. Emile always negates his own being and thus continues to be nothing - a no-habit learner but the most natural learned being. The act of learning of Emile shows an exercise of freedom and responsibility. Rousseau posits that "man is therefore free in his actions and as such is animated by an immaterial substance (Rousseau, 1979, p. 81)."

\section{Emile and the Situation}

Freedom is best understood with a situation, and there is a situation through freedom (Sartre, 1992). It is a fact that Emile's existence is with other existents. The limitation as per the situation in each stage is only an obstacle in relation to consciousness. For instance, when Emile planted the beans, and the beans were dug out by Robert, the beans in relation to Emile are his property, which is why he became outrageous. However, it was Robert's property in relation to himself. Here, Emile is absolutely free. He can either choose to maintain his position of planting the beans and being 
dug out by Robert again, or he can change his meaning of planting the beans as the destruction to Robert's melon. In the end, Emile chooses to consider the beans as the intruder of Robert's melon. The expression of Emile through his decision only depicts the absoluteness of freedom. Emile, therefore, decides to withdraw his gardening on the same lot.

Is Emile responsible? He is absolutely responsible for his freedom because Emile admits his action and all that contains his action, motive, and end, and because he chooses to plant the beans even if it is encouragement by his tutor. Emile acts in good faith, which even brings to a realization of values: justice and ownership.

\title{
Emile's Emotional Experience
}

It must be noted that Emile is allowed to feel pain and even suffer throughout his course of action. For instance, Emile, in his childhood, falls down. He even suffers from being lost in the woods and even feels outrage. This pain, in education, enables Emile to discover something other than feelings themselves. The pain from falling gives way to the act of rising. Wandering makes Emile find his way. Outrage leads to a realization of the importance of securing property and a sense of justice. However, those feelings are not freedom, and the feelings in themselves are not also freedom. Instead, the feelings that Emile experiences are the expressions of his being-for-itself. These feelings are recognized in education to unveil the absoluteness of freedom implicitly.

\begin{abstract}
If by too much care you spare them every kind of discomfort, you are preparing great miseries for them; you make them delicate, sensitive; you cause them to leave man's estate to which they will return one day in spite of you ... for the freedom I give my pupil amply compensates him for the slight discomforts to which I leave him exposed (Rousseau, 1979, p. 86).
\end{abstract}

Just like what Sartre believes, freedom is really something that we are condemned to be. It entails discomfort; it is a constant negation. It is from this negation that one finds absolute freedom.

\section{Emile and His Past Lessons}

At an early age, Rousseau does not believe that history can do something. History, in here, is being-in-itself which does nothing, particularly to learning. However, it is the learner who will do something about history, which is why it is given later. "The facts described by history are far from being an exact portrayal of the same facts as they happened (Rousseau, 1979, p. 238)." Reading history requires a more developed mind to negate it and produce a deeper understanding of the relations of the past and the present being.

The lessons or values that Emile discovers and lives with do not necessarily control or deny his freedom and responsibility. However, the past lessons remain as being-in-itself. It is in absolute freedom of Emile to be conscious of the past lessons. However, in any case, the past lessons or even the past stages cannot define or determine his future being. Take the case of choosing Sophie. There is no determining factor in the being of Emile to say that he would undoubtedly choose Sophie. Although it is evident that Sophie is educated to prepare herself as a wife, it must be taken into consideration that Emile leaves Sophie and decides for himself. What is surprising here is when Emile chooses Sophie to be his wife and declares that he is free upon asking Sophie to be his wife. Authenticity in the decision also manifests absolute freedom. There are no excuses and blaming on the past actions of Emile every time he decides. In that case, the past lesson is the given past that continues to be the object of Emile's consciousness in nihilation - the present facticity. In Emile's event of choosing Sophie, he chooses happiness, which implies that his goal is freedom.

\section{The Tutor: In the Presence of Absolute Freedom and Responsibility}

It is an important consideration that the tutor appears to be and produces the limit or obstacle to Emile's absolute freedom and responsibility. It is the tutor who invents, often, the environment and situation of Emile. The tutor is a good follower of nature as he is the messenger of nature (Johnston, 2001). For instance, in early childhood, the tutor already knows the innate freedom of the learner. The methods to be used must also show the freedom within the learner. 
The spirit of these rules is to accord children more true freedom and less dominion, to let them do more by themselves and to exact less from others. . So we have another very important reason for leaving children's bodies and limbs absolutely free. .. (Rousseau, 1979, p. 68).

Leaving the bodies and limbs absolutely free does not mean that Rousseau's freedom is provided or it is education that gives absolute freedom; however, it is implied that education allows absolute freedom in the learning process. If we consider freedom as an added value to Emile's being and, consequently, an external thing or a being-in-itself, then we would be thinking that the tutor is limiting the freedom of Emile by providing a limited and controlled environment. However, there is no evidence that the tutor is hindering Emile's freedom. Allan Bloom insists that even during the time for travel of Emile, the tutor advised him to leave Sophie. From that, the command of the tutor reveals the dominance of his will over Emile. This is the first time the tutor commands Emile to do something; however, this commandment is actually upon Emile's request to seek advice (Rousseau, 1979). Still, considering freedom as something to be limited is not even expressed by the tutor himself because he even respects freedom as something that goes the limits our consciousness has known. Therefore, it must be established now that there is no such thing as limited freedom even in the role of the tutor as expressed in his relation to Emile; hence, education does not limit nor provide freedom, but it rather facilitates the expressions of freedom.

As a representation of the method of education, the tutor reveals that freedom and responsibility must be respected. The tutor says: "Learn to become your own master. Command your heart, Emile, and you will be virtuous (Rousseau, 1979, p. 445)." It is his goal to align the learning process to let Emile experience his own freedom. Therefore, education is an expression of freedom that sets the highest good to attain in the process. As long as the tutor understands this absoluteness of freedom, he is also free to invent a situation to effectively convey that the learner, like Emile, would surely be conscious of it.

One significant suggestion in Emile is that the tutor must be the parent or, at least, be like a parent. Rousseau has clearly confessed that, towards the end of Emile, it is obviously acted upon by Emile's choice of educating his own son. Just like Emile, the tutor is also absolutely free and responsible. How can the tutor educate Emile if the tutor in himself has limited freedom and responsibility? And how can a learning process be something when it is only confined with the being-in-itself? Learning without becoming will sound ridiculous in the Sartrean concept.

\subsection{Conclusion}

Regardless of man's given or non-given nature, what is clear between Sartre and Rousseau is that a person is born into the world with all other existent beings. Goodness as man's nature does not contradict the idea of freedom since freedom is even the highest good. Though Sartre's expression of freedom appears to be something that is not good since it is a kind of imprisonment, Sartre believes that freedom is absolute. It is what makes man to be.

Does Emile attain the goal of education? It does not matter whether Rousseau concludes that Emile becomes a natural man, a good man, or a free man. What is clear in education and its process is that Emile is absolutely free insofar as he chooses himself; and it is clear that Emile by himself determines what he wishes or what he chooses. As Emile is a natural man, success is not crucial to freedom because freedom itself implies success. Freedom is the being of being-for-itself, and it must choose itself. It is not the satisfaction of what one wishes, but by choosing it is free.

Whereas Emile's existentialist interpretation provides a different perspective of the traditional conception of Rousseau's work, it can now be understood that Emile himself exercises his absolute freedom and responsibility. The new interpretation shows that education can respect the being of the learner. In this way, contemporary education must not be imprisoned by the choice of limitation or facticity. Instead, education must be a channel for limitless imagination and emphasize existential freedom and responsibility in the learning process to create a meaningful and well-being.

The Sartrean freedom and responsibility is an ontological inquiry. It gives us the foundation of providing the importance and recognition of absolute freedom and responsibility in the reality of education. Emile is nothing but total freedom. His freedom indeed leads him to whatever goal of education is laid down unto him. There is certainly freedom in education, and there is education in freedom. 


\section{REFERENCES}

Armitage, P. B. (1990). The relevance of Sartre's philosophy to education (Order No. U044554). Available from ProQuest Dissertations \& Theses Global. (301479625). Retrieved from https://0www.proquest.com.ustlib.ust.edu.ph/dissertations-theses/relevance-sartres-philosophyeducation/docview/301479625/se-2?accountid $=206329$

Arnett, W. M. (1963). Rudolf Bultmann's Existentialist Interpretation of the New Testament. The Asbury Journal, 17(2). https://place.asburyseminary.edu/asburyjournal/vol17/iss2/5

Arnett, W. M (1966). Existentialism in the Thought of Bultmann and Tillich. The Asbury Journal, 20(2). https://core.ac.uk/download/pdf/155820046.pdf

Brosman, C. S. (1985). Theories of collectivities in Sartre and Rousseau. South Central Review, 2(1), 25-41. doi:10.2307/3189408.

Coppleston, Frederick (2003). A History of Philosophy: 19th and 20th Century: French Philosophy. Vol. 9. Continuum

d'Anjou, P. (2007). The existential self as locus of sustainability in design. Design Philosophy Papers, 5(3), 119-128. https://doi.org/10.2752/144871307X13966292017559

Darnell, T. (1992). Sartre's Debt to Rousseau: Freedom, Faith, and Fulfillment. Bulletin de la Société Américaine de Philosophie de Langue Française, 4(2/3), 244-263. https://web.ics.purdue. edu/ smith132/French_Philosophy/Fa92/sartD.pdf

Delaney, James (2009). Starting with Rousseau. Continuum International Publishing Group.

Detmer, D. (2005). Sartre on freedom and education. Sartre Studies International, 11(1), 78-90. https://doi.org/10.3167/135715505780282452

Dilman, I. (2013). Free will: An historical and philosophical introduction. Routledge.

Dinitto, T. (1980). Education and the Philosophy of Jean-paul Sartre (Order No. 8027569). Available from ProQuest Dissertations \& Theses Global. (302955776). Retrieved from https://0-www. proquest.com.ustlib.ust.edu.ph/dissertations-theses/education-philosophy-jean-paul-sartre/ docview/302955776/se-2?accountid $=206329$

Dinkler, E. (1952). Existentialist Interpretation of the New Testament. The Journal of Religion, 32(2), 87-96. http://www.jstor.org/stable/1197359

English, J. C. (1966). Existentialism and the Study of History. Social Science, 153-160. https://www. jstor.org/stable/41885183

Jessop, B. (2018). On academic capitalism. Critical policy studies, 12(1), 104-109.). https://doi.org/10. 1080/19460171.2017.1403342

Johnston, G. (2001). Constitutive Elements of the Discourse of natural Instruction in Rousseau's Emile: Situations and Implications. Romanic Review, 92(3), 245-258.

Jugo, Ian Nicholas (2012). Man's Pursuit for Happiness through the Philosophy of Man. Cebu City: Max Copy Center.

Kearney, R. (2003). Routledge History of Philosophy Volume VIII: Twentieth-Century Continental Philosophy. Routledge.

Koirala, M. P. (2011). Existentialism in education. Academic voices: A Multidisciplinary Journal, 1, 3944. https://doi.org/10.3126/av.v1i0.5309

Kraus, E. R. (1980). The Compatibility of Sartre's Concept of" person" as Found in Being and Nothingness and the Summerhill Environment (Doctoral dissertation, New York University, School of Education, Health, Nursing, and Arts Professions).

Landau, I. (2012). Sartre's absolute freedom in being and nothingness: The problems persist. Philosophy Today, 56(4), 463-473. https://doi.org/10.5840/philtoday20125648

Nash, Paul, Andreas Kazamias \& Henry Perkinson (1965). The Educated Man. Studies in the History of Educational Thought. John Wiley and Sons.

Oelkers, J. (2002). Rousseau and the image of'modern education'. Journal of Curriculum Studies, 34(6), 679-698. https://doi.org/10.1080/00220270210141936

Overholt, G. E. (1969). Freedom, Facticity, And Education: The Educational Implications Of Sartrean Existentialism (Order No. 7006844). Available from ProQuest Dissertations \& Theses Global. (302471475). Retrieved from https://0-www.proquest.com.ustlib.ust.edu.ph/dissertationstheses/freedom-facticity-education-educational/docview/302471475/se-2?accountid=206329

Petcu, C. (2012). Sartre's Emphasis on Individual Consciousness. Linguistic and Philosophical Investigations, 11, 123-128. Retrieved from https://ezproxy.usjr.edu.ph:2293/ docview/1030745645?accountid $=33262$ 
Pitt, Rebecca (2015). (Review) Jean-Paul Sartre: Key Concepts. 108-109. French Studies January 1 , 2015, 69(1):108. Retrieved from http://dx.doi.org/10.1093/fs/knu238

Rousseau, J. J. E. (1979). Emile or on Education, (A. Bloom, Trans). Basic Books. (Original work published 1762).

Sartre, J. P, (2007). Existentialism is a Humanism (C. Macomber, Trans.). Yale University Press. https:// doi.org/10.2307/j.ctv15vwkgx

Sartre, J. P. (1992). Being and Nothingness: A Phenomenological Essay on Ontology (H. E. Barnes, Trans.). Washington Square Press (Original work published 1943).

Schick Jr., Theodore \& Vaughn, Lewis (2006). Doing Philosophy: An Introduction through Thought Experiments (3rd Ed.). McGraw Hill.

Scholz, S. J. (2010). That all children should be free: Beauvoir, Rousseau, and childhood. Hypatia, 25(2), 394-411. https://doi.org/10.1111/j.1527-2001.2010.01102.x

Vandenberg, D. (1967). The Ontological Foundation of Moral education. https://0-www.proquest. com.ustlib.ust.edu.ph/dissertations-theses/ontological-foundation-moral-education/ docview $/ 302339061 /$ se-2?accountid $=206329$

Wall, Thomas F. (2005). On Human Nature: An Introduction to Philosophy. Thomson Wadsworth.

White, D. (2001). Freedom and Responsibility: Existentialism, Gifted Students, and Philosophy.

Gifted Child Today, 24(2), 48-53+. Retrieved from https://ezproxy.usjr.edu.ph:2293/ docview/203256160?accountid $=33262$

Wokler, R. (2001). Rousseau: a very short introduction (Vol. 48). OUP Oxford.

Yap, D., Subingsubing, K., \& Valenzuela, N. G. (2021, January 27). Educators say CHED's proposal to define academic freedom 'laughable'. Inquirer.net. Retrieved February 20, 2021, from https:// newsinfo.inquirer.net/1388690/educators-say-cheds-proposal-to-define-academic-freedomlaughable

\section{Correspondence:}

BELJUN P. ENAYA

beljun.enaya@vsu.edu.ph

https://orcid.org/0000-0003-3506-1252

AL FRANJON VILLAROYA

alfranjon.villaroya@vsu.edu.ph

https://orcid.org/0000-0001-6144-5335 